\title{
Travel Accessibility Criterion of Urban Commuters: Evidence from Hyderabad, Pakistan
}

\author{
Gopal Das ${ }^{1}$, Sabeen Qureshi ${ }^{2}$, Fahad Ahmed Shaikh ${ }^{1}$, Musrat Gul Bhelar ${ }^{1}$ and Mir Aftab Hussain Talpur ${ }^{1}$ \\ ${ }^{I}$ Department of City and Regional Planning, Mehran University of Engineering \& Technology, Jamshoro, Pakistan \\ ${ }^{2}$ Department of Architecture, Mehran University of Engineering \& Technology, Jamshoro, Pakistan \\ Correspondence Author: Gopal Das (gopaldas2010@gmail.com)
}

Received July 14, 2021; Revised August 14, 2021; Accepted August 20, 2021

\begin{abstract}
Travel accessibility is a crucial factor in examining travel and transportation services. However, the lack of suitable transportation facilities often severely affects the daily working schedule of the local inhabitants. Thus, this study aimed to record and examine the accessibility criterion of the commuters of Hyderabad, Pakistan. The data were randomly procured with the help of a questionnaire survey. Total 384 questionnaires were filled from the study to record the accessibility parameter of the local inhabitants. Correlation and frequency tests were performed to analyze data. It was found that local inhabitants in Hyderabad were facing accessibility problems and struggled to reach their destinations efficiently. This study can assist the development authority and traffic department of Hyderabad in formulating relevant policies to mitigate the accessibility problems.
\end{abstract}

Index Terms: Travel Accessibility, Transportation Services, Questionnaire Survey, Correlation Test, Transport Policies.

\section{INTRODUCTION}

An effective transport system plays a crucial role in providing daily supplies in the lives of citizens [1]. This includes access to facilities and services vital to the life of all individuals, like employment, education, and health services recreational and where the inhabitants can effortlessly afford to meet one's basic necessities and services [2]. Land public transport modes include trains, buses, and minibusses; on the other hand, also taxis, trams and trolleybuses, subways, and 'Paratransport' vehicles, for example, rickshaws, bicycles, and motorcycles, where public transport was defined as a service. It covers formal and informal modes (vehicles) in which a customer pays a fee.

Transport is a main domestic expenditure, mostly for lower-income people, and often challenging to control. Exorbitant transportation can reduce economic productivity. Therefore, transportation costs are of concern because they can empower a poor family to access necessary services and livelihoods by enhancing opportunities that can lead to better living conditions [3]. Several countries are enacting legislation that needs transport services to be created accessible recommend the approach of relating affordability to convenience (i.e., the range of opportunities that can touch affordably) rather than concrete mobility, to advance the evaluation of affordability and profits of transport strategies [4].

Scarcity of affordability and accessibility to tolerable transportation systems can consent people to social effortlessness of reaching goods, services, activities, and destinations, which together are called opportunities. It can be defined as the likelihood of interaction and altercation. Alternatively, automobiles are liable for financial growth and development, but it is tragic to know that it can be a significant financial problem. Increased city densities lead to a rise in personal cars and poor route planning. The serious transport-associated externalities are generating increasing congestion, air and noise pollution, exhaustion of non-renewable resources, traffic accidents besides social inequity [5]. The transportation sector is a crucial component to not only regional economies but local and national as well which has a significant role in socio-economic development. The urbanization process in the rural areas of the developing world is much higher due to the lack of employment, health, education, and trade facilities [6].

A change in basic assumptions from mobility-oriented analysis to accessibility-based analysis is taking place in transportation planning [5]. It has given a changed definition of transportation problems and their potential solutions as having important implications for transportation planning. The achievement of sustainable development of two components as per our study includes; System of Integrated Transportation and the Planning of Land Use, which contributes enormously. Therefore, by using the patterns of these components we would be able to scale back their negative impacts on accessibility comprising multi-model level-of-service indicators, and models which measure the travel distances, travel time, and travel costs mandatory by various types of transport system users to access various types of services and activities [7].

In this study, the accessibility criterion of commuters living in the $2^{\text {nd }}$ largest settlement of Sindh, i.e., Hyderabad is investigated. This study can bring new travel 
opportunities to the residents of Hyderabad, as they are not given proper public transport services over the years.

For public sector organizations, accessibility can be tackled as a performance indicator of a land-use transportation system, which can be implemented in any rural-regional study [8].

\section{RESEARCH MATERIALS AND METHODS}

\section{A. Site Selection}

Hyderabad is the second-largest city in Sindh province. The population of Hyderabad is 1,732,693 people (Census 2017). There are four Taluka/Tehsils in the Hyderabad district. It is situated on the East bank of the river Indus and Hyderabad is about $150 \mathrm{~km}$ apart from Karachi. Hyderabad is well-known for its industrial and business centers as well as big markets. Hyderabad city is facing numerous issues among which the transportation drawback is the main problem in current days [9].

Forced expulsions of urban poor from city centers to distant locations have affected their accessibility and affordability to urban substructures and services [10]. Mobility, transportation demand, transportation choices, user details, integration, affordability, land use factors, and transportation system management all affect accessibility [11].

Encroachment on roads and streets in Hyderabad is impacting user mobility, reducing connectivity as passengers have to stop on those routes due to traffic congestion. People's access to basic facilities is hampered by a lack of knowledge about alternative routes and their privileges. Transportation infrastructure construction, on the other hand, benefits only the wealthy because it does not encourage the use of public transportation, thus disadvantages the poor [12-15].

Low-income individuals cannot afford to own a car, and the poor state of public transportation makes it difficult for them to use it. Lack of transportation mode choices does not offer access to the poor as there are not any, footpaths, fight-of-way for cyclists provided, for active transportation [16].

\section{B. Data Collection and Analysis}

A quantitative method for data collection for analyzing precise results is used for this study. Moreover, a random sampling technique was used for the study; a sample size of 384 is selected to obtain the required sample size. Here $\mathrm{N}=$ Total population, to define any population in general [17].

The decisive sample size for this research, in which the sample size was designed using standard methods. Several analysis methods were adopted to manage and graphing the data for which SPSS and Excel were used, respectively. For spotting the routes of transportation and accessibility analysis, Geographical Information System (GIS) was utilized along with scholarly suggestions and recommendations provided by researchers. This research took six months to complete and was started in January 2021 [18].

Closed-ended questionnaires were designed and distributed to local residents, laborers, employees, and nearby surrounding people.
Sample size 384 was designated mainly for fewer wages areas where the use of public transport was excessive. The following areas were considered for data collection; such as Wadhu Wah, Sheedi Goth, and Wahdat Colony from Qasimabad whereas Latifabad Units 8, 9, 10, 11, and 12 were selected from Latifabad Taluka/Tehsil and Pathan Colony, Hala Naaka, Hirabad and Chandni Chowk from Hyderabad City Taluka/Tehsil.

\section{RESULTS AND DISCUSSION}

This section included the data collected through the questionnaire survey. Collected data analyzed through SPSS by correlation method. Analyzed data were plotted in tables and figures, whereas findings were also highlighted in the results.

Table 1. Case Study Areas

\begin{tabular}{|c|c|c|c|}
\hline $\begin{array}{c}\text { Study } \\
\text { Areas }\end{array}$ & Respondents & Percent & $\begin{array}{c}\text { Cumulative } \\
\text { Percent }\end{array}$ \\
\hline Hyderabad City & 144 & $37.5 \%$ & $37.5 \%$ \\
\hline Latifabad & 150 & $39.1 \%$ & $76.6 \%$ \\
\hline Qasimabad & 90 & $23.4 \%$ & $100 \%$ \\
\hline Total & $\mathbf{3 8 4}$ & $\mathbf{1 0 0} \%$ & \\
\hline
\end{tabular}

Table 1, elucidates that among a sample size of 384 respondents, the questionnaire was distributed. These respondents are from three Talukas/Tehsils i.e, Hyderabad City, Latifabad, and Qasimabad. Furthermore, from Hyderabad city, about 144 questionnaires were filled. Additionally, 90 questionnaires were filled from Taluka/Tehsil Qasimabad and the remaining 150 from Taluka/Tehsil Latifabad. This study also inspected the accessibility of the residents to the basic services and facilities. In addition, the distance to reach their destinations and the time is taken to generate trips was also recorded.

Table 2: Travel Distance from Home to Workplace

\begin{tabular}{|c|c|c|c|}
\hline $\begin{array}{c}\text { Travel } \\
\text { Distance }\end{array}$ & Frequency & Percent & $\begin{array}{c}\text { Cumulative } \\
\text { Percent }\end{array}$ \\
\hline $1-4 \mathrm{~km}$ & 179 & $46.6 \%$ & $46.6 \%$ \\
\hline $5-10 \mathrm{~km}$ & 128 & $33.3 \%$ & $79.9 \%$ \\
\hline $10-15 \mathrm{~km}$ & 63 & $16.4 \%$ & $96.4 \%$ \\
\hline Above $15 \mathrm{~km}$ & 14 & $3.6 \%$ & $100 \%$ \\
\hline Total & $\mathbf{3 8 4}$ & $\mathbf{1 0 0} \%$ & \\
\hline
\end{tabular}

Table 2, describes that 179 respondents moved 1-4 kilometers by public transport to reach their workplace and destination, although 128 respondents traveled 5-10 kilometers, 63 respondents moved 10-15 kilometers, and it shows that 14 respondents traveled more than $15 \mathrm{~km}$; it proved that most of the workplaces were reachable and accessible at 1-4 km of distance by using public transport. Figure 1, below shows that 180 people $(40 \%)$ of the sample size stated that there were integrated routes of public transport in Hyderabad city, while 204 (60 \%) people were found to disagree with it. 




Figure 1: Integration in Public Transport Routes

Figure 2, illustrates the amount of time served for approaching public transport, which is 43 percent of the response aggregate. Total time to reach public transport; 36 percent took 5-10 minutes to reach public transport, 43 percent of the response aggregate took 10-15 minutes to reach public transport, 14 percent took 15-30 minutes, and 7 percent took 30-60 minutes.

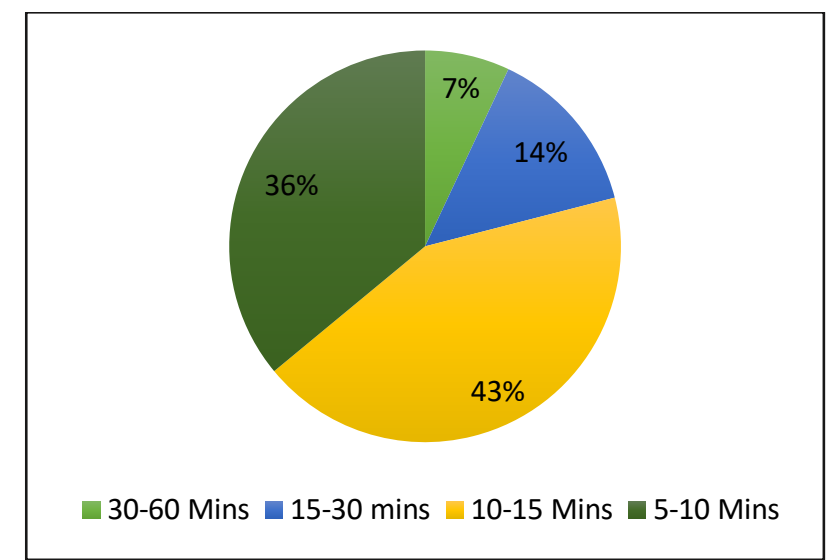

Figure 2: Time to Reach Public Transport

Figure 3, shows that time taken by the respondents to reach their place of interest that was 5 to 10 minutes for 76 respondents, mostly individuals took 10 to 15 minutes to reach the workplace, these were 169 respondents. Moreover, 85 of the total respondents spend 15 to 30 minutes, though 54 of them took 30 to 60 minutes.

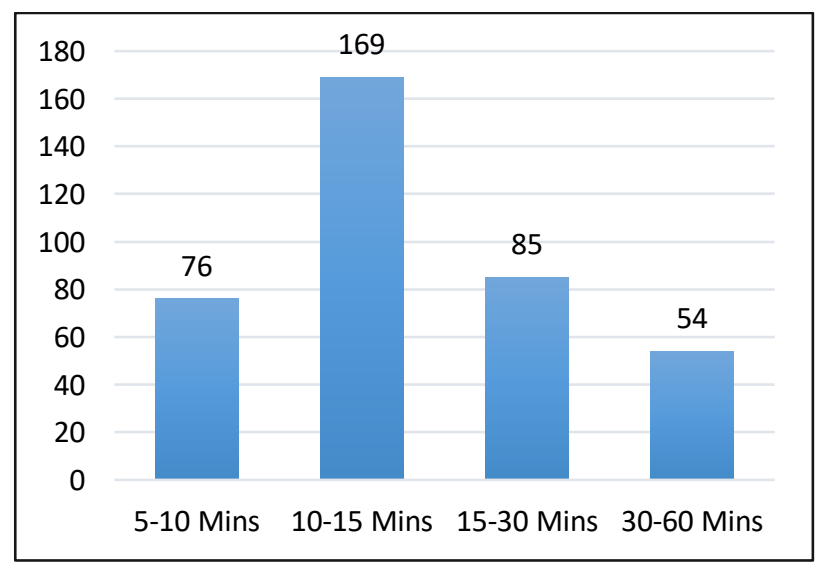

Figure 3: Travel Time
Figure 4, indicates most of the respondents (199 respondents or $52 \%$ ) opinionated that the routes that are declared are not accessible with fluency for reaching towards terminuses, however, others showed agreement with the accessibility opinion towards desired destinations, the number of such respondents is 185 or 48 $\%$.

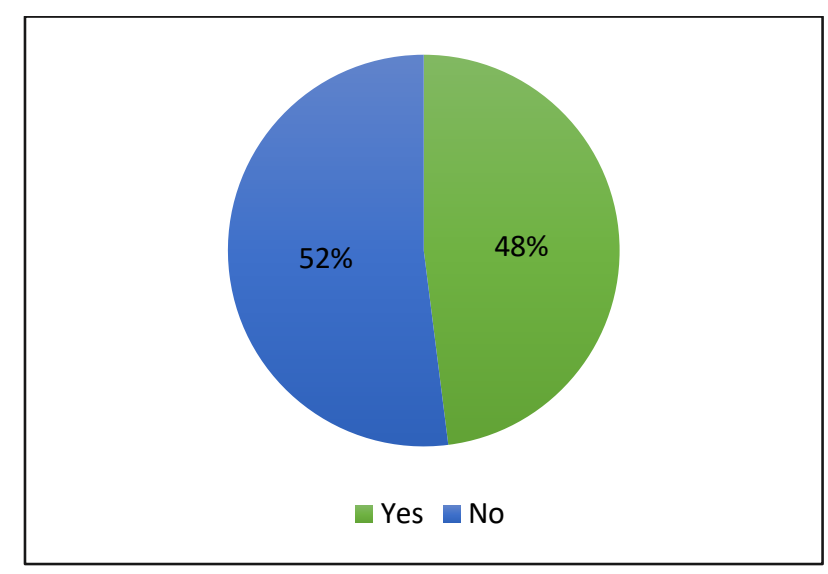

Figure 4: Easy Accessible Routes to Reach Destination

Figure 5, illustrates the coverage of public transport. Total $70(19 \%)$ selected samples showed that public transport moves near to their destination, and $310(81 \%)$ showed that there is a particular route of public transportation.



Figure 5: Public Transport Coverage

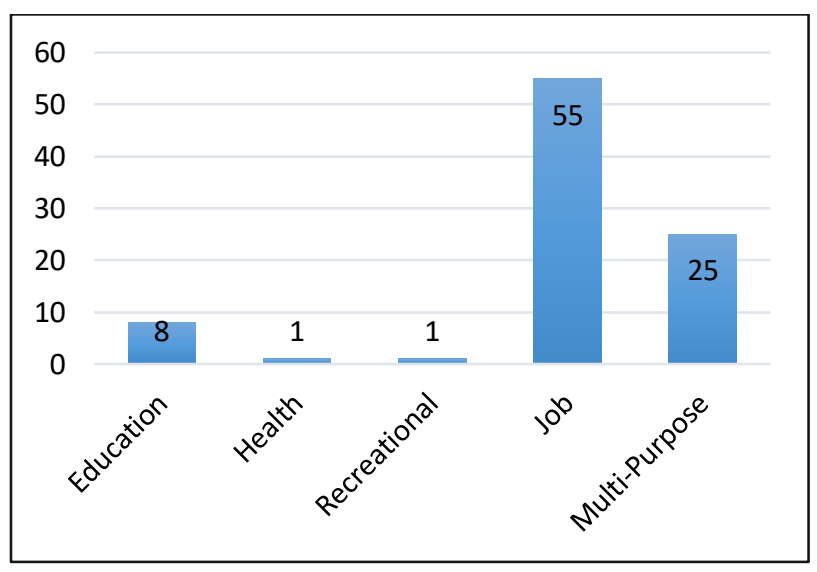

Figure 6: Trip Purposes

The intent for the trips made on daily basis by the respondents is illustrated in figure 6 which indicated that 
the bulk of trips were made for the theme of job that is 55 of the total 90 samples, whereas 25 respondents made trips for multipurpose, which included family, shopping, education. 8 respondents made trips for educational purposes, 1 respondent for health, and 1 for recreational purposes.

Table 3: Correlation Test (Travel Mode and Time)

\begin{tabular}{|c|c|c|c|}
\hline \multirow{2}{*}{$\begin{array}{c}\text { Correlation } \\
\text { tailed })\end{array}$} & Transport use & $\begin{array}{c}\text { Time to reach } \\
\text { the destination }\end{array}$ \\
\hline \multirow{2}{*}{$\begin{array}{c}\text { Transport } \\
\text { use }\end{array}$} & & 1 & $0.19^{* *}$ \\
\cline { 2 - 4 } & $\mathrm{N}$ & 384 & 0.000 \\
\hline \multirow{2}{*}{$\begin{array}{c}\text { Time to } \\
\text { destination }\end{array}$} & & $0.19^{* *}$ & 384 \\
\cline { 2 - 4 } & & 0.000 & 1 \\
\cline { 2 - 4 } & $\mathrm{N}$ & 384 & 384 \\
\hline
\end{tabular}

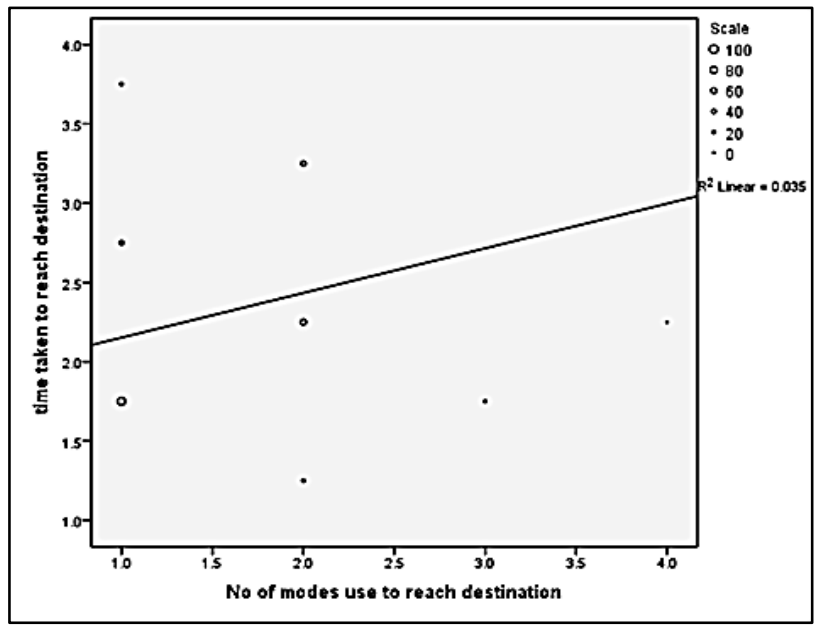

Figure 7: Correlation Test (Travel Mode and Time)

It can visibly be observed in table 3 and figure 7 that the correlation is weak between the variables selected that are transportation modes and the amount of time for reaching destinations in terms of strength and direction. The values of $\mathrm{r}=0.19$ and the $\mathrm{p}$-value is less than 0.01 demonstrating the importance of the relationship.

The association of relationships expounds that the upsurge in several means would automatically create an increase in the time of arrival at the place of desire. Measurement of the potency and the direction i.e., table 4 and figure 8 , degree the potency and the direction of connection between trips/day and time engaged to reach the destination, which exemplifies that the correlation is found weak between the specified variables as $r=-0.101$, but $\mathrm{p}$ is less than 0.05 that means relation is substantial. The correlation particularizes that the additional time is taken by a single trip to reach the destination, then fewer trips will be generated.

Table 4: Correlation Test (Travel Time and Time to Destination)

\begin{tabular}{|c|c|c|c|}
\hline \multicolumn{2}{|c|}{ Correlation (2-tailed) } & $\begin{array}{c}\text { Travel } \\
\text { Time }\end{array}$ & $\begin{array}{c}\text { Time to Reach } \\
\text { Destination }\end{array}$ \\
\hline \multirow{3}{*}{ Travel Time } & & 1 & $-0.101^{*}$ \\
\cline { 2 - 4 } & $\mathrm{N}$ & 384 & 0.050 \\
\hline \multirow{2}{*}{$\begin{array}{c}\text { Time to } \\
\text { Reach } \\
\text { Destination }\end{array}$} & & $-0.101^{*}$ & 384 \\
\cline { 2 - 4 } & & 0.050 & 1 \\
\hline
\end{tabular}

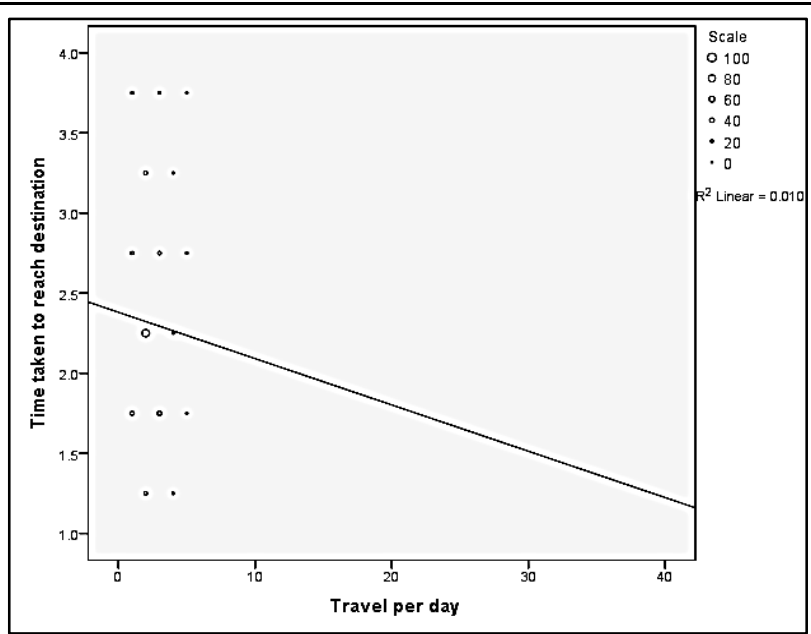

Figure 8: Correlation Test (Travel Time and Time to Reach Destination)

Table 5: Time to Reach Public Transport and Travel Distance (Correlation Test)

\begin{tabular}{|c|c|c|c|}
\hline \multicolumn{2}{|c|}{} & $\begin{array}{c}\text { Time to } \\
\text { Reach } \\
\text { Correlation (2-tailed) }\end{array}$ & $\begin{array}{c}\text { Travel Distance } \\
\text { Public } \\
\text { Trom Home to } \\
\text { Workplace }\end{array}$ \\
\hline $\begin{array}{c}\text { Time to Reach } \\
\text { Public } \\
\text { Transport }\end{array}$ & $\mathrm{N}$ & 1 & $0.160^{* *}$ \\
\cline { 2 - 4 } & & 384 & 0.002 \\
\hline $\begin{array}{c}\text { Travel Distance } \\
\text { from Home to } \\
\text { Work Place }\end{array}$ & Place & $0.160^{* *}$ & 384 \\
\cline { 2 - 4 } & 0.002 & 1 \\
\hline
\end{tabular}

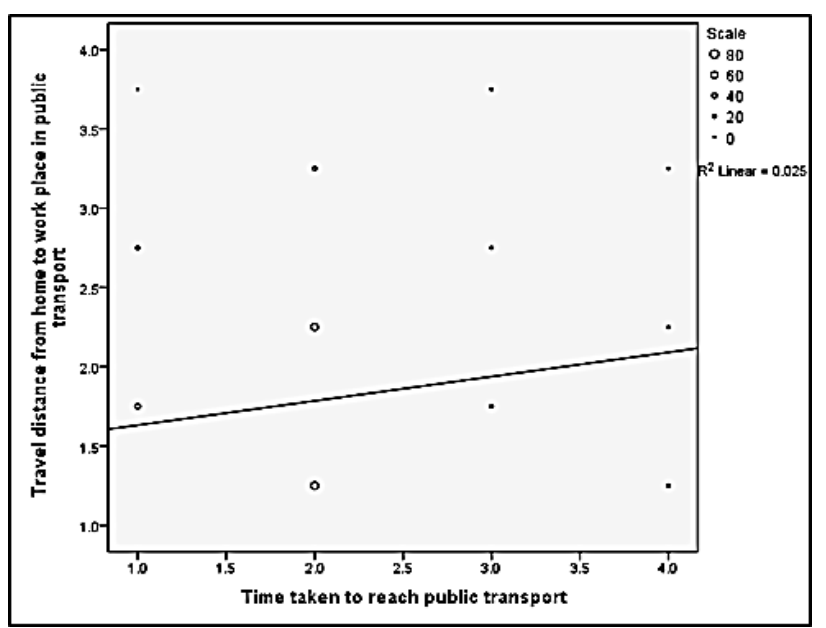

Figure 9: Correlation Test (Time to Reach Public Transport Travel Distance)

Table 5 and figure 9 extent the direction and the strength of the relationship of variables that are time and traveling distance using local conveyance, demonstrating the weak relationship as the significance of relationship can be observed by values i.e., $r=0.160$, whereas the value of $\mathrm{p}$ is less than 0.01 . This explains when the supplementary time has been taking to reach public transport concurrently, the home to workplace traveling in local mode will also upsurge.

\section{CONCLUSION}

From the data analyzed it's found that there is unplanned conveyance provision within the study area, that is not in access to the majority of the residents, the $60 \%$ of the 
residents said, the routes do not appear to be incorporated, and therefore the transport does not run over the whole city, thanks a lot to the ability of inhabitants to access basic utilities and their workplaces deteriorate. In data analysis, $80 \%$ said the general public transport turns from different areas i.e., it takes time for people to attain their workplaces or other desired destinations. While the areas within which the inhabitants can access transportation, two main issues are stopping the commuters to use transport which is consistency and the social condition of the general public transport correspondingly.

The physical state of public transportation was very poor; it was observed that the vehicles are extremely old, with the age of 10 years or more, which makes it a waste of time to reach the destination, for example, the distance that should take 15 minutes, now takes 25-30 minutes. People do not find it convenient to fly by public transportation due to lack of upkeep, even though it serves as an extensible mode of transportation.

External factors influencing mobility and decreasing the use of public transportation, such as poor road conditions and traffic congestion, were discovered during an observational survey. The routes were not readily available, according to $68 \%$ of respondents, $48 \%$ of locals who were told about public transportation schedules were either on time or late. People are forced to purchase private cars due to lack of use of public transportation, which implicitly reduces commuters' mobility to meet their everyday needs because more trips imply more spending.

The lack of planning and enforcement of planning, zoning codes, and the lack of supervision of new construction has a huge impact on people's accessibility, as job opportunities and basic services are far from the living area. According to this observation, it is understood that there is no suitable terminal building for public transport that is easily accessible to residents. In the correlation analysis, it was found that the additional stops/terminals were farther apart, the longer it took to reach the destination. This analysis gave a negative result. Only 16 $\%$ of passengers travel more than 10-15 kilometers, so 53 $\%$ believe public transport is insufficient for long-distance travel.

\section{Acknowledgment}

At first, all praise belongs to Almighty Allah, the most merciful and the most beneficent for giving me the ability to complete the paper. I want to express my deep sense of gratitude to all my associates who helped me in writing this precious paper.

Gopal Das Menghwar, Masters in the Department of City and Regional Planning, MUET Jamshoro, Research Associate in City and Regional planning MUET Jamshoro. Dr. Sabeen Qureshi, Ph.D. in Urban and Regional Planning, Architecture Department, MUET, Jamshoro. Fahad Ahmed Shaikh, Masters in City and Regional Planning, Assistant Professor in City and Regional Planning Department, MUET Jamshoro. Musrat Gul, Masters in City and Regional Planning Department, MUET Jamshoro. Dr. Mir Aftab Hussain Talpur, Ph.D. in Transportation Engineering and Planning, Associate
Professor in City and Regional Planning Department, MUET Jamshoro.

\section{Authors Contributions}

Gopal Das has selected the topic and design the methodology of the paper and also revised the paper. Sabeen Qureshi collected the literature review and design the questionnaire. Fahad Ahmed Shaikh collected the data of the research paper. Musrat Gul Bhelar analyzes and interpretation of data. Mir Aftab Hussain Talpur reviewed the overall research paper and gave suitable suggestions to make the research paper valuable.

\section{Conflict of Interest}

There is no conflict of interest between all the authors

\section{Data Availability Statement}

The study did not find any report of data.

\section{Funding}

No funding was allotted for this research. All the expenses were afforded by all author contributions.

\section{References}

[1] Fouracre, P. R., Sohail, M., \& Cavill, S. (2006). A participatory approach to urban transport planning in developing countries. Transportation Planning and Technology, 29(4), 313-330.

[2] Isalou, A. A., Litman, T., \& Shahmoradi, B. (2014). Testing the housing and transportation affordability index in a developing world context: A sustainability comparison of central and suburban districts in Qom, Iran. Transport policy, 33, 33-39.

[3] Venter, C. (2011). Transport expenditure and affordability: The cost of being mobile. Development Southern Africa, 28(1), 121140.

[4] Suen, S. L., \& Mitchell, C. G. B. (2000). Accessible transportation and mobility. Transportation in the New Millennium.

[5] Litman, T. (2014). Towards more comprehensive and multi-modal transport evaluation. Tech. Rep., Victoria Transport Policy Institute, 2014.

[6] Bertolini, L., Le Clercq, F., \& Kapoen, L. (2005). Sustainable accessibility: a conceptual framework to integrate transport and land use plan-making. Two test applications in the Netherlands and a reflection on the way forward. Transport policy, 12(3), 207220.

[7] Nayak, S., \& Keskar, Y. M. (2014). Impact of foreign direct investment over the city form, a case of Hyderabad city, India. Int J Innov Res Sci Eng Technol, 2(2).

[8] Anokye, M., Abdul-Aziz, A. R., Annin, K., \& Oduro, F. T. (2013) Application of queuing theory to vehicular traffic at a signalized intersection in Kumasi-Ashanti region, Ghana. American International Journal of Contemporary Research, 3(7), 23-29.

[9] Talpur, M. A. H., Napiah, M., Chandio, I., \& Khahro, S. H. (2012). Transportation Planning Survey Methodologies for the Proposed Study of Physical and Socio-economic Development.. Modern Applied Science, 6(7).

[10] Isalou, A. A., Litman, T., \& Shahmoradi, B. (2014). Testing the housing and transportation affordability index in a developing world context: A sustainability comparison of central and suburban districts in Qom, Iran. Transport policy, 33, 33-39.

[11] Venter, C. (2011). Transport expenditure and affordability: The cost of being mobile. Development Southern Africa, 28(1), 121140.

[12] Suen, S. L., \& Mitchell, C. G. B. (2000). Accessible transportation and mobility. Transportation in the New Millennium.

[13] Litman, T. (2014). Towards more comprehensive and multi-modal transport evaluation. Tech. Rep., Victoria Transport Policy Institute, 2014 
[14] Talpur, M. A. H., Napiah, M., Chandio, I. A., \& Khahro, S. H. (2013). Research framework focusing on transportation accessibility planning, computer-based modeling, and transportation policy outlines for remote regions of the developing world. Research Journal of Environmental and Earth Sciences, $5(1), 32-40$.

[15] Bertolini, L., Le Clercq, F., \& Kapoen, L. (2005). Sustainable accessibility: a conceptual framework to integrate transport and land use plan-making. Two test applications in the Netherlands and a reflection on the way forward. Transport policy, 12(3), 207220.

[16] Talpur, M. A. H., Chandio, I. A., Memon, I. A., Napiah, M., \& Jafri, K. H. (2016). A brief review on the role of regional transport accessibility in the development process of distant sub-regions. Indian Journal of Science and Technology, 9(13), 1-9.

[17] Nayak, S., \& Keskar, Y. M. (2014). Impact of foreign direct investment over the city form, a case of Hyderabad city, India. Int J Innov Res Sci Eng Technol, 2(2).

[18] Anokye, M., Abdul-Aziz, A. R., Annin, K., \& Oduro, F. T. (2013). Application of queuing theory to vehicular traffic at signalized intersection in Kumasi-Ashanti region, Ghana. American International Journal of Contemporary Research, 3(7), 23-29. 